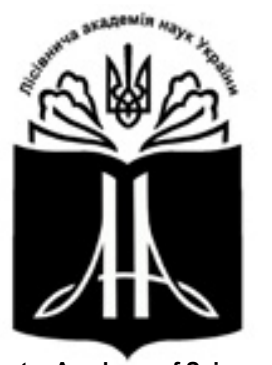

Forestry Academy of Sciences of Ukraine

Наукові праці Лісівничої академії наук України Proceedings of the Forestry Academy of Sciences of Ukraine

http://fasu.nltu.edu.ua https://doi.org/10.15421//411907

Article received 2018.09.24

Article accepted 2019.03.28
ISSN 1991-606X print

ISSN 2616-5015 online

(a) $\triangle$ Correspondence author Svitlana Los svitlana los@ukr.net

Pushkinska str., 86, Kharkiv, 61024, Ukraine

\title{
Особливості розвитку крон дуба звичайного (Quercus robur L.) на клонових насінних плантаціях у Харківській області
}

\author{
С.А. Лось ${ }^{1}$, О.М. Годований ${ }^{2}$
}

Представлено результати досліджень розвитку крон клонів плюсових дерев дуба звичайного (Quеrсиs robur L.) на трьох клонових насінних плантаціях (КНП) в Харківській області віком 35 і 40 років з розміщенням садивних місиь $5 \times 5$ м та $10 \times 5$ м. На КНП представлені клони плюсових дерев з Харківської і Сумської областей.

Проаналізовано результати досліджень, проведених на КНП у 1999 і 2018 рр. У прочесі вивчення розвитку крон на КНП дуба звичайного у не менш, ніж у трьох рамет кожного клону, визначали висоту дерева, діаметр проекцї крони та розраховували об'єм продуктивної (з погляду репродукції) частини крони. За показниками розмірів крони визначали оптимальну кількість дерев на КНП.

Відзначено низьку та середню індивідуальну мінливість між клонами за висотою крони, середню - за діаметром проекиії крони, високу і підвищену - за об'ємом репродуктивної частини крони. Визначено клони, які суттєво перевищують середні показники по КНП за висотою і діаметром проекцї крони, тобто мають найкраще розвинені крони.

Зафіксовано переваги за висотою дерев на КНП 35-річного віку за розмішення $5 \times 5$ м, тоді як найбільші показники діаметра крони та об'єму продуктивного шару крони відзначено на 40-річній КНП з розміщенням щуеп $10 \times 5$ м. Виявлено, щзо до змикання крон у міжряддях спостерігається інтенсивніший розвиток крони у ширину, а після змикання - у висоту.

Для покращення умов освітлення та живлення дерев $і$ збереження наявного продуктивного шару крони доцільно з 15-20 років здійснювати селективне зрідження. Оптимальна кількість дерев має розраховуватися на основі показника середнього діаметру проекції крони. Тривала експлуатація КНП дуба звичайного є доцільною за умови здійснення своєчасних зріджувань і збереження максимальних розмірів продуктивної частини крони.

Ключові слова: клон; висота; діаметр проекції крони; продуктивна частина крони.

Вступ. Важливим чинником насінної продуктивності клонової насінної плантації (КНП), окрім репродуктивної спроможності клонів, $\epsilon$ ступінь розвитку крон щеплених дерев. За однакової інтенсивності плодоношення кількість отриманих плодів і насіння $з$ дерев, що відрізняються більшими розмірами крон, буде більшою. Тому під час відбору і встановлення селекційної цінності плюсових дерев важливими є показники розмірів крон їхніх клонів. Крім того, інформація щодо розмірів крон клонів у певному віці дає можливість надати практичні рекомендації щодо ефективної відстані між деревами на плантації.

В Україні у минулому більше уваги приділено дослідженням форми крони клонів сосни звичайної на КНП (Mazhula, 2005). Фінськими

Лось Світлана Анатолївна - член-кореспондент Лісівничої академії наук України, кандидат сільськогосподарських наук, завідувач лабораторії селекції. Український науково-дослідний інститут лісового господарства та агролісомеліорації ім. Г. М. Висоцького, вул. Пушкінська, 86, м. Харків, 61024, Україна. Тел.: 057-707-80-77, +38-097-138-97-92. E-mail: svitlana_los@ukr.net ORCID: https:// orcid.org/0000-0002-6341-2745

Годований Олексій Миколайович - провідний інженер-аналітик відокремленого підрозділу «Харківська лісонасіннєва лабораторія» Державна організація «Український лісовий селекційний центр», проспект Московський, 202 м. Харків, 61082, Україна. +38-097-44936-68, E-mail: godovanyy.a@gmail.com 
вченими (Ruotsalinen \& Antola, 2017) розроблена комп'ютерна програма, яка порівнює кожну щепу із сусідніми і дає можливість оцінити кожен клон за фенотипом (розміром, станом), а також допомагає у виборі варіанту зрідження. Після першого зрідження КНП І-го покоління (400 шт./га) залишають близько 150-170 шт./га, після другого - 90 шт./га. Густота КНП 1,5-го покоління, зазвичай, становить близько 250 шт./га, а після першого зрідження - 135 шт./га.

Корейські науковці, розглядаючи особливості репродукції клонів на КНП Quercus acutissima Carruth (Kima, Kanga \& Parka, 2016), виявили мінливість клонів як за об'ємом крони, так і за урожайністю, підкресливши важливість доброго освітлення крон для формування репродуктивних органів. Для характеристики параметрів дерев на КНП ними використано декілька показників і методик, зокрема, для визначення об' єму крони запропоновано алгоритм розрахунку об'єму біконуса. У нашій попередній роботі (Los, Godovaniy \& Gubin, 2017) розглянуті особливості розвитку крон та репродукції дуба звичайного на насінних плантаціях ДП «Гутянське ЛГ» Харківської обл. та оцінено клони і родини, представлені на них, за станом, репродукцією та ступенем розвитку крон. Розміри крон та прогнозування їхнього розвитку важливе також для проектування насаджень в озелененні (Martin, Chappelka \& Somers, 2012).

На жаль, кількість наукових публікацій, які б висвітлювали зазначені проблеми, обмежена. Залишаються актуальними питання міжклонової мінливості за розмірами крони, та визначення ступеню впливу густоти розташування дерев на цей показник.

Варто зазначити, що питанням розвитку крон приділяють значну увагу у плодівництві (Kondratenko, 2012, Chaploutskyi \& Melnyk, 2016,

Balabak \& Balabak, 2016). Адже архітектоніка крон дерев впливає на різні аспекти розвитку рослин, включаючи акумулювання сонячної енергії, індукцію квіткових бруньок, урожайність і якість плодів (Lauri, Terouanne \& Kelner, 1995). Незважаючи на те, що архітектура дерев є генетично керованою, на неї можуть впливати місце посадки, температуpa, світло, вітер, грунт (Shi, 2015). Крім того, існує думка, що на певному етапі продуктивного життя плодового дерева починає проявлятися негативна кореляція між зростанням врожайності дерева i збільшенням розміру його крони. Так, дослідженнями Кейна (Theoretical, 1979) встановлено, що зі збільшенням діаметра крони плодового дерева від 2,5 до 10 м продуктивність на одиницю площі крони зменшується більш ніж на 150 г на кожні $0,09 \mathrm{M}^{2}$ приросту площі крони. Це призводить до того, що дерево 3 діаметром крони 10 м формує врожай плодів на одиницю площі, займаної кроною, наполовину менший, ніж дерево того ж сорту, яке має діаметр крони 2,5 м. Тому, одним із завдань нашого дослідження $\epsilon$ перевірка гіпотези про наявність такої ж закономірності у дуба звичайного.

Об'єкти та методика досліджень. Об' $є к m$ дослідження - клонове насінництво дуба звичайного. Предмет дослідження - динаміка розвитку крон клонів дуба звичайного на КНП. Мета досліджень полягала в аналізі розвитку крон клонів дуба звичайного на КНП з різним розміщенням садивних місць.

Дослідження проводили на трьох КНП у Харківській обл., створених садінням щеплених саджанців із закритою кореневою системою в умовах свіжого груду (табл. 1). Варто зазначити, що за такого способу створення КНП крони щеп клонів починаються майже від рівня грунту.

Таблиия 1

Характеристика обстежених КНП

\begin{tabular}{lccrc}
\hline \multicolumn{1}{c}{ Місцезнаходження } & $\begin{array}{c}\text { Рік } \\
\text { створення }\end{array}$ & $\begin{array}{c}\text { Розміщення } \\
\text { садивних } \\
\text { місць }\end{array}$ & $\begin{array}{c}\text { Кількість } \\
\text { прдставлених } \\
\text { клонів, шт. }\end{array}$ & $\begin{array}{c}\text { Вік } \\
\text { рокеження, }\end{array}$ \\
\hline ДП «Харківська ЛНДС», Південне лісництво, кв. 129 & 1979 & $10 \times 5$ м & 54 & $20 / 40$ \\
\hline ДП «Харківська ЛНДС», Південне лісництво, кв. 129 & 1985 & $5 \times 5$ м & 36 & $15 / 35$ \\
\hline $\begin{array}{l}\text { ДП «Чугуєво-Бабчанський лісгосп», Кочетоцьке л-во, } \\
\text { кв. } 297\end{array}$ & 1985 & $10 \times 5$ м & 20 & $15 / 35$ \\
\hline
\end{tabular}

На КНП представлені клони плюсових дерев із Харківської і Сумської областей. Шифри клонів у табл. 2-4 складаються з перших літер назв лісгоспів або лісництв, де вони були відібрані (Д - Данилівський лісгосп, К - Кочетоцьке л-во, Л - Люботинське л-во, М - Мерчанське л-во, П - Печенізьке л-во, Су - Сумський лісгосп, Тє - Тєтлєзьке л-во, Та - Таранівське л-во, Тр - Тростянецький лісгосп, Ш Шарівське л-во) та номеру дерева по господарству.

Проаналізовано результати обстеження, проведеного восени 2018 р., коли плантації мали вік 40 та 35 років. Для розрахунків використано також ре- зультати обмірів 1999 р., коли плантації мали вік 20 i 15 років, відповідно. Прирости за висотою і діаметром крони визначали за два періоди. Перший період - від часу створення до обстеження у 1999 р. та від 1999 до 2018 року.

Під час вивчення розвитку крон на КНП дуба звичайного у не менш ніж трьох рамет кожного клону визначали висоту дерева за допомогою висотоміра, діаметр проекції крони - за допомогою мірної стрічки у двох напрямках (у ряду і міжрядді).

За основу визначення об'єму крони щеп взято формулу розрахунків об'єму еліпсоїда: 


$$
\mathrm{V}=4 / 3 \times \pi \times 1 \times \mathrm{r}^{2},
$$

де $1-1 / 2$ висоти крони дерева, $r$ - радіус проекції крони дерева (рис. 1).

У плодівництві використовують такий показник, як «продуктивна частина крони» (Kolesnikov, 1979) або «продуктивна частини листового намету» (Kudryavec, 2010). Враховуючи те, що жолуді дуба звичайного формуються на кінцях гілок, розташованих у метровому периферичному шарі крони, нами запропоновано розрахунок продуктивної частини крони за наступною формулою:

$$
\mathrm{V}=\mathrm{k} \times\left(4 / 3 \times \pi \times 1 \times \mathrm{r}^{2}-\left(4 / 3 \times \pi \times(1-2) \times(\mathrm{r}-1)^{2}\right)\right),
$$

де $\mathrm{k}$ - корегуючий коефіцієнт, який залежить від нижнього рівня розташування гілок крони.

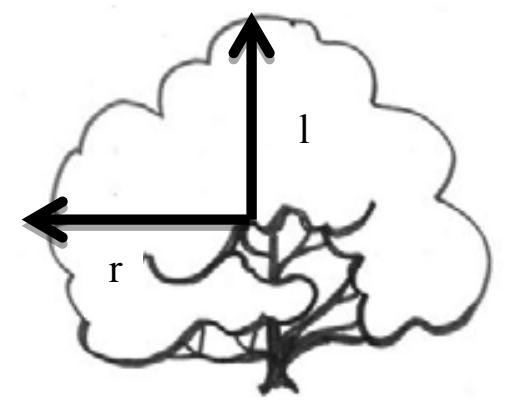

Рис. 1. Схема визначення об'єму крони щеп клонів дуба звичайного

Запропоновано розраховувати оптимальну кількість дерев на КНП за формулою:

$$
\mathrm{N}=10000 /((\mathrm{d}+1) \times(\mathrm{d}+1)),
$$

де $\mathrm{d}$ - середній діаметр проекції крони щеп на КНП (м). До показника діаметра додано 1 м, як мінімальну відстань вільного простору для забезпечення освітленості крон.

Отримані дані опрацьовували методами варіаційної статистики з використанням пакету програм MC EXEL. Статистичну значущість різниць між показниками крони визначали за t-критерієм Стьюдента. Рівень мінливості характеристик крони оцінювали за шкалою Mamaev (1972).

Результати досліджень. За результатами обстеження у 2018 р. збереженість щеп на КНП становила в середньому $31 \%$, а їхній стан, в основному, був добрим і задовільним.

Середні показники висот дерев та діаметрів крон клонів на КНП 1979 р. створення у 40-річному віці подано у табл. 2.

Обстеження 31-го клону показало, що середня висота щеп коливалася у межах від 9,1 (К-36) до 15,0 м (П-8) і становила в середньому 13,3 м. Відзначено низьку мінливість між клонами за цим показником $(\mathrm{V}=11,5 \%)$. Порівняння $з$ середнім значенням по КНП за критерієм Стьюдента виявило суттєву перевагу чотирьох клонів (М-4, П-8, П-18, П-20, Су-27). Суттєво меншою висотою у порівнянні $з$ середнім показником характеризувалися три клони (К-36, Тє-5 і Ш-8).

Середній діаметр крони клонів коливався у межах від 6,3 (Тр-2) до 12,3 м (П-8) і становив у серед- ньому 12,1 м. Рівень мінливості між клонами за цим показником середній $(\mathrm{V}=16,5 \%)$. Суттєво більший від середнього значення діаметр крони мали лише два клони (П-8 і П-24), а суттєво менший - чотири (Д-5, П-14, Тр-2 і Ш-8). При цьому клон П-8 мав перевагу за обома показниками, а клон Ш-8, відповідно, відставав. Різниця між діаметрами проекцій крон, відповідно, у міжряддях і рядах становила в середньому 2,1 м.

Нижні гілки крон на КНП знаходяться на висоті 2-3 м над рівнем грунту, що складає близько $20 \%$ висоти дерева, тому для розрахунку об'єму продуктивної частини крони клонів було взято корегуючий коефіцієнт 0,8. За наведеними даними в табл. 2 , об'єм продуктивної частини крони суттєво варіює між клонами - від 130,3 (Тр-2) до 373,4 (П-8) м³. Рівень мінливості цього показника за шкалою Мамаєва - підвищений ( $\mathrm{V}=29,2 \%)$. Переважна більшість клонів характеризується об'ємом продуктивної частини крони більше $200 \mathrm{M}^{3}$, а клони М-4, П-8, П-18, П-20, П-24, Су-27 і Та-7 - більше 300 м².

Порівнюючи показники розмірів крон у 20 і 40 років (рис. 2), можемо відмітити, що висоти дерев збільшилися вдвічі, проте середні річні прирости за висотою протягом останніх 20 років збільшилися незначно і майже не змінювалися протягом 40 років. 3 іншого боку, діаметри крони збільшилися лише на $35 \%$, а середні показники річних приростів за діаметром крони за останні 20 років зменшилися більш ніж удвічі.

Отже, впродовж перших 20-ти років на КНП відбувалося більш інтенсивне збільшення крон щеп у ширину, ніж у висоту, а в наступні 20 років - навпаки, крона збільшувалася головним чином у висоту. Причина полягає в тому, що крони в 20 років вже зімкнулися в рядах і майже зімкнулися в міжряддях. Тепер гілки крон сусідніх дерев перекривають одна одну не лише в рядах, але й у міжряддях. За нашими розрахунками, середній річний приріст діаметра проекції крони клонів на КНП становив 0,25 м. Можна передбачити, що у наступні роки почнеться всихання нижніх гілок і зменшення об'єму продуктивного шару крони. Для покращення умов освітлення, живлення дерев і збереження продуктивного шару крони на КНП доцільно провести селективне зрідження 3 видаленням частини дерев у рядах 3 тим, щоб залишилося не більше 60 щеп на 1 га.

На КНП 1985 р. створення у Південному лісництві ДП «Харківська ЛНДС» за даними обстежень 1999 і 2018 рр. (табл. 3) у 20 років щепи мали широкі крони, краще розвинені за діаметром, ніж за висотою, а в 35-річному віці форма крон стала більш видовженою. Так, у 35 років середня висота щеп становила від 9,2 (Тє-5) до 16,4 (Ш-6) м, в середньому - 13,8 м. Відмічено низьку мінливість між клонами за цим показником $(\mathrm{V}=12,8 \%)$. Суттєво більшими висотами за їхнє середнє значення на КНП характеризувалися чотири клони (Д-3, П-8, Та-3 і Ш-6), суттєво меншими - три клони (К-32, Тє-4 і Ш-2). Середній діаметр крони коливався між клонами у межах від 4,4 (Тє-4) до 10,1 
(К-36) м і становив в середньому 7,8 м. Рівень мінливості між клонами за цим показником - середній $(\mathrm{V}=17,8 \%)$. Суттєво переважали середнє значення діаметра крони шість клонів (Д-2, Д-3, К-36, П-8, Ш-6 і Ш-7) та істотно відставали два клони
(Ш-8 і Тє-4). За обома показниками достовірно перевищували контроль лише клони Д-3 і П-8 (див. табл. 3). Варто зазначити, що величини діаметрів проекцій крон в рядах і міжряддях на цій плантації не відрізнялися.

Таблиия 2

\section{Середні показники стану і розмірів крон 40-річних щеп клонів дуба звичайного} на КНП 1979 р. створення у ДП «Харківська ЛНДС»

\begin{tabular}{|c|c|c|c|c|c|c|c|}
\hline \multirow{2}{*}{ Шифр клону } & \multicolumn{3}{|c|}{ Висота дерева, м } & \multicolumn{3}{|c|}{ Діаметр крони, м } & \multirow{2}{*}{$\begin{array}{l}\text { Об'єм продуктивної } \\
\text { частини крони, } \text { м }^{3}\end{array}$} \\
\hline & $\mathbf{M}$ & $\mathbf{m}$ & $\mathbf{t}$ & M & $\mathbf{m}$ & $\mathbf{t}$ & \\
\hline Д-3 & 13,0 & 0,7 & 0,3 & 9,4 & 0,9 & $-0,3$ & 230,1 \\
\hline Д-5 & 13,2 & 0,2 & 0,7 & 7,7 & 0,6 & $-2,1^{*}$ & 176,7 \\
\hline K-26 & 12,3 & 0,6 & $-0,4$ & 9,4 & 0,9 & $-0,3$ & 220,0 \\
\hline K-31 & 11,5 & 0,7 & $-1,2$ & 10,0 & 0,3 & 0,2 & 226,0 \\
\hline K-33 & 11,5 & 0,7 & $-1,2$ & 9,9 & 0,8 & 0,1 & 225,1 \\
\hline K-35 & 12,3 & 0,2 & $-0,5$ & 10,5 & 0,9 & 0,6 & 256,8 \\
\hline K-36 & 9,1 & 1,0 & $-3,0^{*}$ & 8,4 & 1,6 & $-0,8$ & 146,3 \\
\hline K-38 & 10,8 & 1,3 & $-1,3$ & 9,1 & 0,4 & $-0,8$ & 188,8 \\
\hline Л-3 & 13,4 & 0,8 & 0,7 & 10,2 & 1,1 & 0,3 & 261,9 \\
\hline Л-5 & 12,4 & 0,9 & $-0,3$ & 10,4 & 0,9 & 0,5 & 253,1 \\
\hline Л-7 & 14,1 & 1,2 & 1,0 & 10,3 & 1,4 & 0,3 & 278,3 \\
\hline Л-8 & 11,6 & 0,5 & $-1,2$ & 8,8 & 0,9 & $-0,9$ & 189,1 \\
\hline M-4 & 14,7 & 0,2 & $2,7 *$ & 12,0 & 1,0 & 1,7 & 352,7 \\
\hline П-8 & 15,0 & 0,8 & $2,1^{*}$ & 12,3 & 0,1 & $3,1^{*}$ & 373,4 \\
\hline$\Pi-14$ & 12,1 & 0,7 & $-0,6$ & 7,7 & 0,6 & $-2,1^{*}$ & 163,0 \\
\hline П-18 & 14,7 & 0,2 & $2,8^{*}$ & 11,5 & 0,5 & 1,8 & 335,9 \\
\hline П-20 & 14,5 & 0,5 & $2,2 *$ & 11,3 & 1,1 & 1,1 & 323,2 \\
\hline П-21 & 12,9 & 0,8 & 0,2 & 9,4 & 0,5 & $-0,4$ & 228,4 \\
\hline П-23 & 12,6 & 0,6 & $-0,1$ & 9,4 & 0,6 & $-0,4$ & 222,7 \\
\hline П-24 & 12,9 & 0,7 & 0,2 & 13,3 & 1,2 & $2,5^{*}$ & 372,8 \\
\hline Cy-27 & 15,3 & 0,9 & $2,3 *$ & 11,0 & 0,9 & 1,0 & 324,8 \\
\hline Та-7 & 13,9 & 0,5 & 1,4 & 11,9 & 1,3 & 1,4 & 336,9 \\
\hline Тa-13 & 11,9 & 0,9 & $-0,7$ & 10,8 & 1,8 & 0,5 & 260,3 \\
\hline Тa-18 & 13,2 & 0,5 & 0,5 & 10,2 & 1,0 & 0,3 & 260,1 \\
\hline T€-5 & 9,9 & 0,9 & $-2,5^{*}$ & 8,1 & 0,7 & $-1,6$ & 147,6 \\
\hline Tp-2 & 12,8 & 0,4 & 0,1 & 6,3 & 1,0 & $-2,6^{*}$ & 130,3 \\
\hline Tp-15 & 12,9 & 0,6 & 0,2 & 6,9 & 0,9 & $-2,5^{*}$ & 145,9 \\
\hline Ш-2 & 14,2 & 0,4 & 1,8 & 10,1 & 0,9 & 0,2 & 270,3 \\
\hline Ш-3 & 12,7 & 0,8 & 0,0 & 9,3 & 0,4 & $-0,5$ & 222,6 \\
\hline Ш-4 & 12,3 & 0,6 & $-0,4$ & 9,3 & 0,4 & $-0,6$ & 215,7 \\
\hline Ш-8 & 10,6 & 0,6 & $-2,3^{*}$ & 7,8 & 0,6 & $-2,0^{*}$ & 149,0 \\
\hline Середне & 12,7 & & & 9,8 & & & 241,6 \\
\hline $\mathrm{V}, \%$ & 11,5 & & & 16,5 & & & 29,2 \\
\hline
\end{tabular}

* Різниця суттєва на $95 \%$ рівні значущості

Гілки крони щеп на осліджуваній КНП підняті досить високо і починаються приблизно на середині висоти дерев, тому під час розрахунку об'єму продуктивної частини крони було застосовано коригуючий коефіцієнт 0,5 . Показник об'єму продуктивної частини крони різних клонів тут коливався від 35,9 (Тє-4) до 168,8 (Д-3) м³ і в середньому ста- новив $118,0 \mathrm{~m}^{3}$. Відносний рівень мінливості - підвищений $(\mathrm{V}=30,5 \%)$. Найбільшими кронами характеризувалися клони Д-3, К-36, П-8 і Ш-6.

На рис. 3 представлено динаміку середніх показників висоти дерев і діаметрів проекції крон на КНП 1985 р. створення. Діаграми демонструють, що і в 15 і в 35 років крони дерев були дещо видо- 
вженими, висота була більшою, ніж діаметр крони, і ця різниця з віком помітно збільшилася. Так, висоти крон щеп збільшилися за останні 20 років на $136 \%$, а середні річні прирости за висотою збільшилися незначно і майже не змінювалися протягом всього часу існування КНП. Середні показники річних приростів за діаметром крони за останні 20 років вдвічі зменшилися, а діаметри крони протягом останніх 20 років збільшилися лише на $73 \%$. Го- ловною причиною слабкого розвитку крон у латеральному напрямку і втрати половини продуктивного шару крони можна вважати початкове загущене розташування дерев на КНП $(5 \times 5$ м). Тепер для покращення умов освітлення та живлення дерев і збереження наявного продуктивного шару крони на цій КНП доцільно провести селективне зрідження 3 видаленням частини дерев у рядах і міжряддях та залишенням не більше 100 дерев на 1 га.

Таблиия 3

Середні показники розмірів крон клонів дуба звичайного на КНП 1985 р. у ДП «Харківська ЛНДС»

\begin{tabular}{|c|c|c|c|c|c|c|c|}
\hline \multirow{2}{*}{ Шифр клона } & \multicolumn{3}{|c|}{ Висота, м } & \multicolumn{3}{|c|}{ Діаметр крони, м } & \multirow{2}{*}{$\begin{array}{l}\text { V продуктивної } \\
\text { частини крони, м}\end{array}$} \\
\hline & $\mathrm{M}$ & $\mathrm{m}$ & $\mathrm{t}$ & $M$ & $\mathrm{~m}$ & $t$ & \\
\hline Д-2 & 13,3 & 0,9 & $-0,6$ & 8,7 & 1,0 & 0,8 & 130,2 \\
\hline Д-3 & 16,0 & 1,0 & $2,1^{*}$ & 9,4 & 0,4 & $3,4 *$ & 168,8 \\
\hline Д-5 & 14,4 & 0,6 & 0,9 & 6,6 & 0,3 & $-3,8^{*}$ & 94,5 \\
\hline К-32 & 12,5 & 0,5 & $-2,4^{*}$ & 7,1 & 0,7 & $-1,1$ & 93,9 \\
\hline К-36 & 13,8 & 0,5 & $-0,1$ & 10,1 & 0,5 & $3,9^{*}$ & 165,2 \\
\hline Л-3 & 13,2 & 1,6 & $-0,4$ & 6,6 & 0,9 & $-1,4$ & 88,0 \\
\hline Л-8 & 14,3 & 0,7 & 0,7 & 8,1 & 0,7 & 0,3 & 126,8 \\
\hline П-8 & 15,8 & 0,3 & $5,6^{*}$ & 8,8 & 0,3 & $2,2 *$ & 151,7 \\
\hline П-20 & 14,8 & 1,3 & 0,7 & 7,6 & 1,2 & $-0,3$ & 118,9 \\
\hline Тa-3 & 15,2 & 0,3 & $4,0^{*}$ & 7,7 & 0,5 & $-0,4$ & 123,9 \\
\hline Te-4 & 9,2 & 1,3 & $-3,5^{*}$ & 4,4 & 0,7 & $-5,0 *$ & 35,9 \\
\hline Ш-2 & 12,0 & 0,9 & $-2,1^{*}$ & 7,7 & 0,7 & $-0,4$ & 100,6 \\
\hline Ш-3 & 12,7 & 1,0 & $-1,2$ & 7,1 & 0,6 & $-1,3$ & 95,0 \\
\hline Ш-4 & 14,8 & 0,8 & 1,1 & 8,1 & 0,5 & 0,2 & 128,5 \\
\hline Ш-6 & 16,4 & 0,7 & $3,4^{*}$ & 9,2 & 0,8 & 1,6 & 167,4 \\
\hline Ш-7 & 14,6 & 0,8 & 0,9 & 8,7 & 0,2 & $2,5^{*}$ & 141,1 \\
\hline Ш-8 & 12,4 & 1,3 & $-1,1$ & 6,2 & 0,9 & $-1,9$ & 75,9 \\
\hline Середнє & 13,8 & & & 7,8 & & & 118,0 \\
\hline $\mathrm{V}, \%$ & 12,8 & & & 17,8 & & & 30,5 \\
\hline
\end{tabular}

* Різниця суттєва на 95 \% рівні значущості

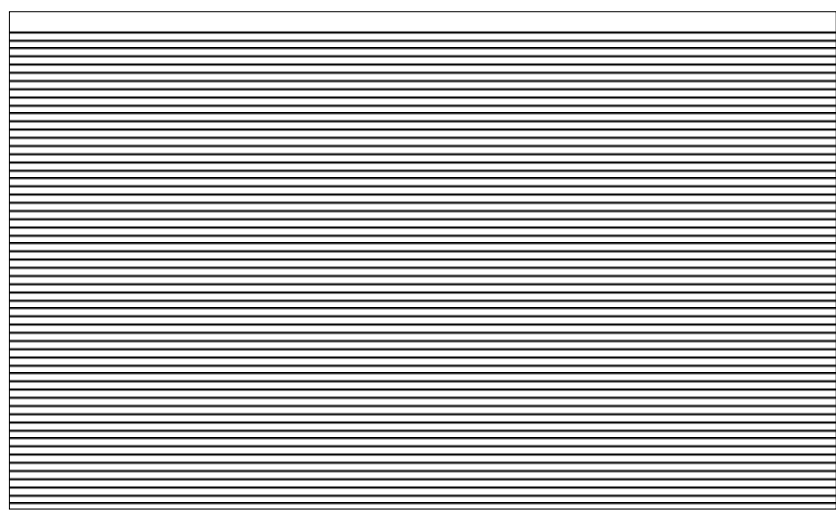

Рис. 2. Динаміка середніх показників розмірів крон на КНП 1979 р. створення

у Південному лісництві ДП «Харківська ЛНДС»

На КНП 1985 р. створення у Кочетоцькому л-ві ДП «Чугуєво-Бабчанське ЛГ» у віці 35 років середня висота щеп окремих клонів коливалася у межах від 7,0 м (П-23) до 12,4 м (П-24) і становила у середньому 8,7 м (табл. 4). Відмічено середню мінливість між клонами за цим показником $(\mathrm{V}=17,4 \%)$. За висотою жоден 3 клонів суттєво не перевищував і не відставав від середнього показника по КНП.

Середній діаметр крони щеп варіював у клонів від 6,7 (П-20) до 10,8 (Та-18) м і його середнє значення для усієї плантації становило 8,1 м. Рівень мінливості між клонами за цим показником є середнім $(\mathrm{V}=18,0 \%$ ). За діаметром крони суттєво перевищували середнє його значення на КНП два клони (К-36 і Та-18). Решта клонів за цим показником слабо відрізняються від контролю. Різниця між діаметрами проекцій крон в міжряддях і рядах становила 1,7 м.

На характеризованій КНП нижній рівень гілок крони щеп клонів знаходиться на висоті 1-2 м, тому під час розрахунку об'єму продуктивного шару використано корегуючий коефіцієнт 0,9. Значення об'єму продуктивної частини крони різних клонів коливаються від 106,9 (К-33) до 243,4 (Та-18) м і в середньому становило $146,4 \mathrm{~m}^{3}$. Рівень мінливості цього показника - підвищений $(\mathrm{V}=36,1 \%)$. Найбільшим об'ємом продуктивної частини крони характеризуються клони К-36, П-24 і Та-18. 
Середні показники розмірів крон клонів дуба звичайного на КНП 1985 р. у Кочетоцькому Л-ві ДП «Чугуєво-Бабчанське ЛГ»

\begin{tabular}{lccccccc}
\hline \multirow{2}{*}{$\begin{array}{l}\text { Шифр } \\
\text { клону }\end{array}$} & \multicolumn{5}{c}{ Висота, м } & \multicolumn{5}{c}{ Діаметр крони, м } & Об’єм продуктивної \\
\cline { 2 - 6 }${\text { частини крони, } \mathrm{m}^{3}}^{\text {М }}$ & $\mathrm{m}$ & $\mathrm{t}$ & $\mathrm{M}$ & $\mathrm{m}$ & $\mathrm{t}$ & 113,6 \\
\hline Д-5 & 8,3 & 1,2 & $-0,7$ & 6,8 & 0,8 & $-1,8$ & 110,9 \\
К-30 & 7,9 & 1,9 & $-0,7$ & 6,9 & 0,9 & $-1,4$ & 106,9 \\
К-33 & 7,9 & 0,8 & $-1,5$ & 6,8 & 1,1 & $-1,4$ & 213,4 \\
К-36 & 9,2 & 0,7 & 0,0 & 9,9 & 1,0 & 1,5 & 132,8 \\
П-9 & 7,3 & 1,2 & $-1,5$ & 8,1 & 1,2 & $-0,2$ & 114,9 \\
П-20 & 8,8 & 1,7 & $-0,2$ & 6,7 & 2,0 & $-0,8$ & 116,2 \\
П-23 & 7,0 & 1,7 & $-1,2$ & 7,6 & 1,7 & $-0,4$ & 242,9 \\
П-24 & 12,4 & 2,1 & 1,5 & 9,3 & 0,3 & $2,2 *$ & 166,0 \\
Та-7 & 9,3 & 0,9 & 0,1 & 8,3 & 0,8 & 0,0 & 243,4 \\
Та-18 & 9,2 & 1,1 & 0,0 & 10,8 & 0,8 & $2,9 *$ & 146,4 \\
Середнє & 8,7 & & & 8,1 & & & 36,1 \\
V, \% & 17,4 & & & 18,0 & & & \\
\hline
\end{tabular}

* Різниця суттєва на 95 \% рівні значущості

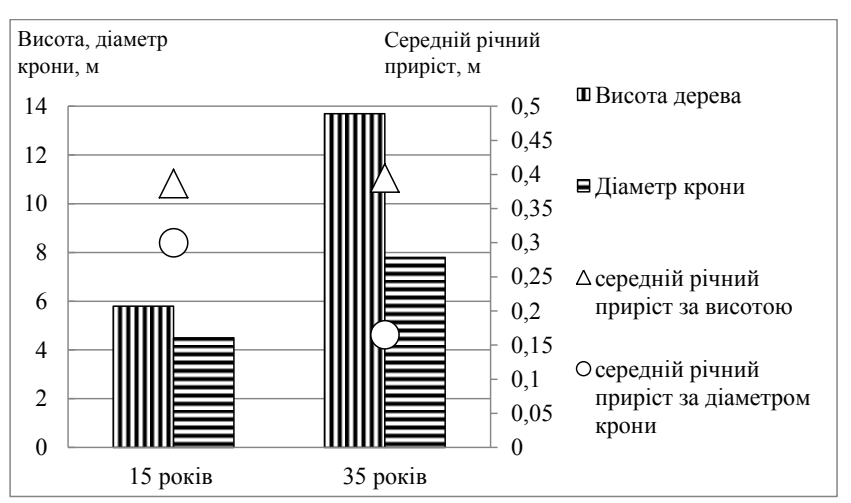

Рис. 3. Динаміка середніх показників розмірів крон щеп на КНП дуба звичайного 1985 р. створення

у Південному лісництві ДП «Харківська ЛНДС»

Динаміка середніх показників висоти дерев i діаметрів проекції крон на КНП 1985 р. створення у Кочетоцькому лісництві дещо відрізняється від попередніх КНП (рис. 4). Тут відмічається досить рівномірний ріст за висотою і діаметром крон протягом всього періоду спостережень. Так, висота щеп клонів збільшилися за останні 20 років на $123 \%$, а діаметр крони - на $125 \%$. Середні річні прирости як за висотою, так і за діаметром крони майже не змінювалися протягом всього часу існування КНП. Крони дерев зімкнулися лише в рядах, а в міжряддях ще залишився вільний простір для їхнього розвитку. Потрібне незначне зрідження плантації в рядах. Розрахункова оптимальна кількість дерев - 100 шт./га.

Узагальнюючи отримані дані потрібно зазначити, що найбільш інтенсивний розвиток крон у висоту зафіксовано на КНП 1985 р. створення у Південному л-ві, на якій густота садіння була найбільшою (схема розміщення щеп $5 \times 5$ м). Діаметр проекції крони на цій КНП, навпаки, був меншим у порівнянні з КНП 1979 р. створення $(5 \times 10$ м), але май- же не відрізнявся від такого ж показника на КНП в Кочетоцькому л-ві. Найбільшими значеннями показника об'єму продуктивного шару крони характеризувалися щепи клонів на КНП 40-річного віку 3 розміщенням садивних місць $10 \times 5$ м. Серед КНП 35-річного віку переваги за розмірами крон мають щепи на плантації з розміщенням садивних місць $10 \times 5$ м (рис. 5).

\begin{tabular}{|c|c|c|c|c|}
\hline \multicolumn{2}{|c|}{$\begin{array}{l}\text { Висота, діаметр } \\
\text { крони, м }\end{array}$} & \multicolumn{2}{|c|}{$\begin{array}{l}\text { Середній річний } \\
\text { приріст, м }\end{array}$} & \multirow[b]{2}{*}{ ш Висота дерева } \\
\hline 10 & & 0,265 & \\
\hline 9 & \multicolumn{2}{|l|}{$\triangle$} & 0,26 & \multirow{3}{*}{ Е Діаметр крони } \\
\hline 8 & & & 0,255 & \\
\hline 7 & & & 0,25 & \\
\hline 6 & & & 0,245 & \multirow{3}{*}{$\begin{array}{l}\Delta \text { середній річний } \\
\text { приріст за висотою }\end{array}$} \\
\hline 5 & 0 & & \multirow{2}{*}{$\begin{array}{l}0,24 \\
0,235\end{array}$} & \\
\hline 4 & & & & \\
\hline ? & & & 0,23 & \multirow{3}{*}{$\begin{array}{l}\text { Осередній річний } \\
\text { приріст за діаметром } \\
\text { крони }\end{array}$} \\
\hline 1 & & & \multirow{3}{*}{$\begin{array}{l}0,225 \\
0,22\end{array}$} & \\
\hline 0 & & & & \\
\hline & оків & ків & & \\
\hline
\end{tabular}

Рис. 4. Динаміка середніх показників розмірів крон на КНП дуба звичайного 1985 р. створення у Кочетоцькому лісництві ДП «Чугуєво-Бабчанське ЛГ»

Кореляційний аналіз не виявив зв' язків між розмірами крон щеп клонів та інтенсивністю їхньої репродукції.

Враховуючи те, що за різних схем розміщення клони плюсових дерев в одному віці можуть мати різні розміри крон, оптимальна кількість дерев на КНП має визначатися з урахуванням реальних діаметрів проекцій крон. Результати таких розрахунків представлені на рис. 6а. Так, у 20 років за середнього діаметра крони 7 м кількість дерев на КНП не має перевищувати 156 шт./га, а у віці 35 років за середнього діаметра проекції крони 10,5 м на КНП потрібно залишити не більше 75 дерев на 1 га. 


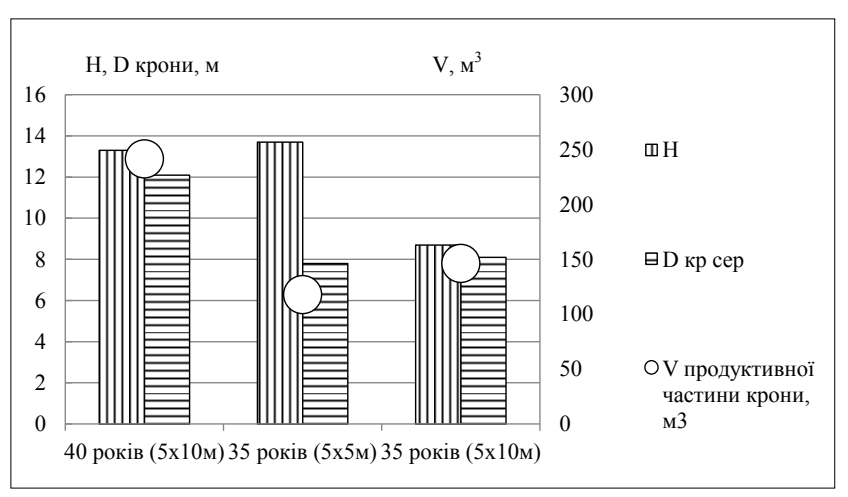

Рис. 5. Середні по КНП показники розвитку крон щеплених дерев на КНП дуба звичайного

Множенням об'єму середнього дерева на розрахункову оптимальну кількість дерев встановлено показник сумарного по КНП об'єму продуктивної частини крон. Враховуючи те, що за оптимальної відстані між деревами гілки крон щеп дуба, за-

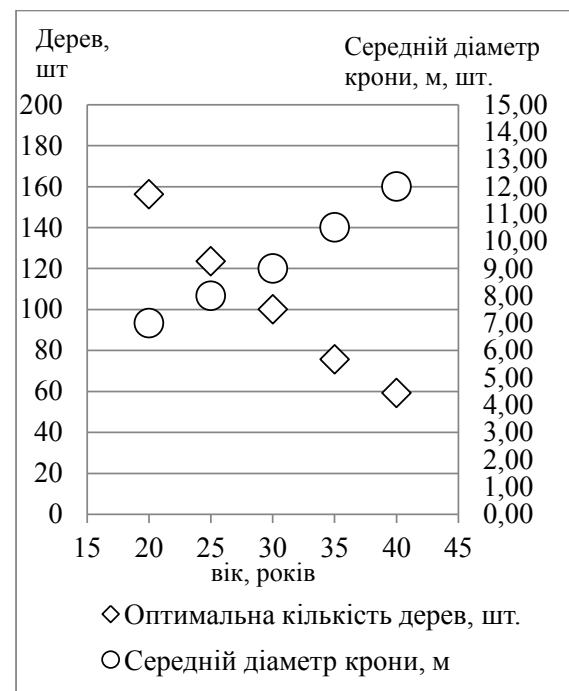

звичай, знаходяться на рівні 2-3 м над поверхнею грунту, використано корегуючий коефіцієнт 0,8 . Результати розрахунків представлені на рис. 6б. Незважаючи на те, що кількість дерев у віці 40 років зменшується майже втричі у порівнянні з початковою, сумарний по КНП об'єм продуктивної частини крон збільшується, причому рівень кореляційного зв'язку між показниками дуже високий $(\mathrm{r}=-0,99)$.

Отже враховуючи те, що інтенсивність репродукції залежить від індивідуальних особливостей клонів (Los, 2017), а не від розмірів крон, а сумарний по КНП об'єм продуктивної частини крон за зменшення кількості дерев на 1 га збільшується, закономірності щодо зменшення врожайності при збільшенні розмірів крон, притаманної плодовим деревам, на КНП дуба нашими дослідженнями не виявлено. 3 іншого боку, за здійснення своєчасних зріджувань і збереження максимальних розмірів продуктивної частини крони тривала експлуатація КНП дуба звичайного є доцільною.

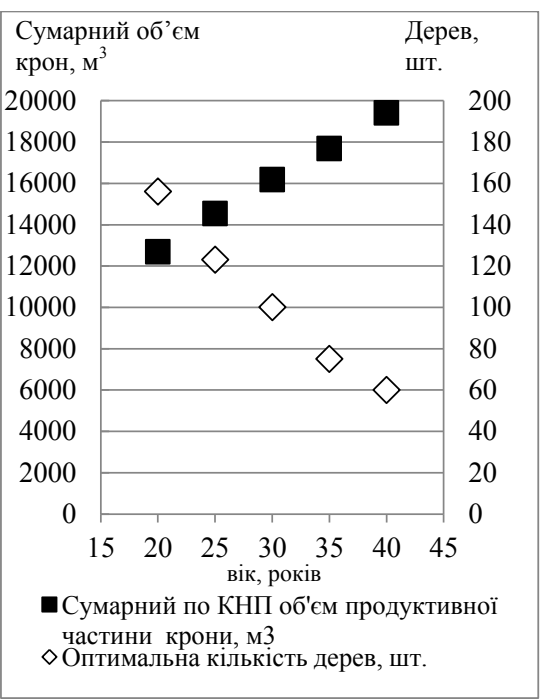

Рис. 6. а) Оптимальна розрахункова кількість дерев на КНП дуба звичайного залежно від середнього діаметру крони; б) Сумарний по КНП об’єм продуктивної астини крон за оптимальної розрахункової кількості дерев

Висновки. На КНП дуба звичайного у віці 15, $20,35,40$ років виявлено низький та середній рівень індивідуальної мінливості між клонами дуба звичайного за висотою $(\mathrm{V}=11,5-17,4 \%)$, середній за діаметром проекції крони $(\mathrm{V}=16,5-18,0 \%)$ та високий і підвищений - за об'ємом продуктивного шару крони $(\mathrm{V}=29,2-36,1 \%)$.

Суттєво перевищують середні показники КНП одночасно за висотою і діаметром проекції крони лише три клони: Д-3, П-8, Ш-6. Найбільшими об'ємами продуктивної частини крони на КНП 40-річного віку у Південному л-ві вирізнялися клони М-4, П-8, П-18, П-20, П-24. Су-27 і Та-7. На КНП 35-річного віку у Південному л-ві кращими за цим показником були клони Д-3, К-36, П-8 і Ш-6, а у Кочетоцькому л-ві - клони К-36, П-24 і Та-18. Кореляційний аналіз не виявив зв'язків між розмірами крон щеп клонів та інтенсивністю їхньої репродукції.
Виявлено закономірності формування крон дуба звичайного на КНП, а саме те, що до змикання крон у міжряддях відзначено інтенсивніший розвиток крон у ширину, а після змикання - у висоту.

Початкове розміщення щеп на КНП $5 \times 5$ м є небажаним, оскільки стримує розвиток їхніх крон у ширину та спричиняє втрату половини продуктивної частини крон. За розміщення щеп $10 \times 5$ м формується широка розлога крона, що сприяє інтенсивнішій репродукції.

Для покращення умов освітлення та живлення дерев і збереження наявного продуктивного шару крони доцільно 3 15-20 років здійснювати селективне зрідження. Оптимальну кількість дерев необхідно розраховувати для кожної КНП на основі показника середнього діаметра проекції крони. Тривала експлуатація КНП дуба звичайного $є$ доцільною за умови проведення своєчасних зріджувань і збереження максимальних розмірів продуктивної частини крони. 


\section{Бібліографічні посилання}

Balabak, O.A., \& Balabak, A. V. (2016) Influence of plantations design on lightness of crown and yield of hazelnut (Corylus domestica Kosenko et Opalko) Balanced natural resources, 4, 52-54 (in Ukrainian).

Chaploutskyi, A.M., \& Melnyk, O.V. (2016) Parameters of crown of apple trees depending on the method and the period of pruning. Collected Works of Uman National University of Horticulture, 88 (1), 218-224 (in Ukrainian).

Kima, H.-T., Kanga, J. W., Leeb, W.Y., Hanb, S. U., \& Parka E.-J. (2016) Estimation of acorn production capacity using. Forest Science and Technology, 12 (1), 51-54. https://doi.org/10.1080/21580103.2015.1 026412

Kondratenko, T. Ye. (2012) History and current state of apple cultivars in Ukraine. Scientific journal of nules of Ukraine: Agronomy, 180, 45-53. Retrieved from: http://nbuv.gov.ua/UJRN/nvnau_agr_2012_180_8

Kudriavets, R.P. (2010). Formation and pruning of garden trees. Moscow: AST Publishing House «Astrel» (in Russian).

Lauri, P. E., Lauri, P. E., Térouanne, E., Lespinasse, J. M., Regnard, J.L., \& Kelner, J.J. (1995). Genotypic differences in the axillary bud growth and fruiting pattern of apple fruiting branches over several years an approach to regulation of fruit bearing. Scientia Horticulturae, 64 (4), 265-281. https://doi. org/10.1016/0304-4238(95)00836-5

Los, S.A., Godovaniy O.M., Grigorieva V.G., \& Gubin Ye. A. (2017). The oak trees crown development and reproduction on seedling and clonal seed orchards at the Hutyanske forestry enterprise of Kharkiv region. Forestry and Forest Melioration, 131, 87-95 (in Ukrainian).

Los, S. (2017). Dynamics of reproductive processes on English oak (Quercus robur L.) clonal seed orchards in the left-bank Forest-Steppe of Ukraine. Proceedings of the Forestry Academy of Sciences of Ukraine, 15, 64-72. https://doi.org/10.15421//411708 (in Ukrainian).

Mamaev, S. A. (1972). Forms of intraspecific variability of woody plants. Moscow: Science (in Russian).

Martin, N.A., Chappelka, A.H., Loewenstein, E.F., Keever, G. J., \& Somers G. (2012). Predictive open-grown crown width equations for three oak species planted in a southern urban locale. Arboriculture \& Urban Forestry 38 (2), 58-63 Available from: http://joa.isa-arbor.com/articles. asp? JournalID $=1 \&$ VolumeID $=38 \&$ IssueID $=2$

Mazhula, O.S. (2005). The structure of the pinetree crown (Pinus sylvestris L.): a hereditary or ecologically conditioned trait? Forestry And Forest Melioration, 108,147-151 (in Ukrainian).

Ruotsalinen, S., \& Antola, J. (2017). Effect of genetic thinning of Scots pine seed orchards // IUFRO Seed orchard conference. Sweden: SKOGFORSK.

Shi, B. (2015). Growth parameters of 'Golden Delicious' apple trees (Malus $\times$ domestica Borkh).
Theses and Dissertations. Purdue University. West Lafayette, Indiana.

Theoretical substantiation of the optimal parameters of the crown (1979). Fruit growing / Ed. V.A. Kolesnikov / Moscow: Kolos (in Russian).

\section{Особенности развития крон дуба обыкновенного на (Quercus robur L.) на клоновых семенных плантациях в Харьковской области}

\author{
С. А. Лось ${ }^{1}$, А.Н. Годованый ${ }^{2}$
}

Важнейшим звеном продуктивности клоновых семенных плантаций, кроме репродуктивной способности клонов, является степень развития крон привитых деревьев. При одинаковой интенсивности плодоношения количество полученных плодов и семян с деревьев, отличающихся большими размерами крон, будет больше. Поэтому при отборе и определении селекционной ценности плюсовых деревьев важны показатели размеров крон их клонов. В работе представлены результаты исследований развития крон клонов плюсовых деревьев дуба обыкновенного (Quercus robur L.) из Харьковской и Сумской областей на трех КНП в Харьковской области в возрасте 35 и 40 лет с размещением посадочных мест $5 \times 5$ м и $10 \times 5$ м.

При изучении развития крон на КНП дуба обыкновенного не менее, чем в трех рамет каждого клона определяли высоту дерева, диаметр проекции кроны и рассчитывали объем продуктивной части кроны. Предложен расчет оптимального количества деревьев на КНП, который базируется на среднем диаметре проекции кроны клонов на КНП.

Отмечено низкую и среднюю индивидуальную изменчивость между клонами по высоте кроны, среднюю - по диаметру проекции кроны, высокую и повышенную - по объему продуктивной части кроны. Разница диаметров проекций крон соответственно в междурядьях и рядах составила в среднем 2,1 м.

Определены клоны, которые существенно превышают средние показатели по КНП одновременно по высоте и диаметру проекции кроны (Да-

Лось Светлана Анатольевна - член-корреспондент Лесной академии наук Украины, кандидат сельскохозяйственных наук, заведующий лабораторией селекции. Украинский научноисследовательский институт лесного хозяйства и агролесомелиорации им. Г.Н. Высоцкого, ул. Пушкинская, 86, г. Харьков, 61024, Украина. Тел.: 057-707-80-77, +38-097-138-97-92. E-mail: svitlana_los@ukr.net ORCID: https://orcid.org/00000002-6341-2745

Годованый Алексей Николаевич - ведущий инженер-аналитик отдельного подразделения «Харьковская лесосеменная лаборатория» Государственная организация «Украинский лесной селекционный центр» проспект Московский, 202, г. Харьков 61082, Украина +38-097-449-36-68, E-mail: godovanyy.a@, gmail.com 
ниловка-3 и Печенеги-8). Наиболее развитые кроны на разных КНП имеют клоны Даниловка-3, Кочеток-36, Мерчик-4, Печенеги-8, 18, 20, 24, Суммы-27, Тарановка-18 та Шаровка-6. Корреляционный анализ не выявил связи между размерами крон привоев клонов и интенсивностью их репродукции.

Зафиксированы преимущества по высоте клонов на КНП 35-летнего возраста при размещении $5 \times 5$ м, тогда как наибольшие показатели диаметров кроны и объема продуктивного пласта кроны отмечено на 40-летней КНП с размещением привоев $10 \times 5$ м. Выявлено, что до смыкания крон в междурядьях наблюдается более интенсивное развитие кроны в ширину, а после смыкания - в высоту.

Размещение клонов на КНП 5 × 5 м нежелательно, поскольку такое размещение сдерживает развитие крон в ширину и вызывает потерю половины продуктивной части кроны. При их размещении $10 \times 5$ м формируется широкая раскидистая крона, что способствует более интенсивной репродукции.

Для улучшения условий освещения, питания деревьев и сохранения продуктивной части кроны целесообразно с 15-20 лет проводить селективное изреживание. Оптимальное количество деревьев нужно рассчитывать на основе показателя среднего диаметра проекции кроны. Длительная эксплуатация КНП дуба обыкновенного целесообразна при условии проведения своевременных изреживаний и сохранении максимальных размеров продуктивной части кроны.

Ключевые слова: клон; высота; диаметр проекции кроны; продуктивная часть кроны.

\section{Features of English oak (Quercus robur L.) crowns development on clonal seed orchards in Kharkiv region}

\section{S. Los' ${ }^{1}$, O. Godovaniy ${ }^{2}$}

The most important factor in the productivity of clonal seed plantations, in addition to the reproductive ability of clones, is the degree of crowns development of grafted trees. By the same fruiting intensity, the

Svitlana Los - Corresponding Member of the Forestry Academy of Sciences of Ukraine, PhD in Agricultural Sciences, Head of laboratory of forest tree breeding of Ukrainian Research Institute of Forestry and Forest Melioration named after G. M. Vysotsky, Pushkinska str., 86, Kharkiv, 61024, Ukraine. Tel.: 057-707-8077, +38-097-138-97-92. E-mail: svitlana_los@ukr.net ORCID: https://orcid.org/0000-0002-6341-2745

Oleksiy Godovanyi - Leading engineer-analyst of the Separated Subdivision «Kharkiv timber seed laboratory», State Organization «Ukrainian Forest Selection center», prospekt Moskovskyi 202, Kharkiv 61082 Ukraine. +38-097-449-36-68 E-mail: godovanyy.a@gmail.com number of fruits and seeds obtained from trees with large crowns will be higher. The difference in the crowns projections diameter, respectively, between the rows and in rows was on average $2.1 \mathrm{~m}$.

Therefore, when selecting and evaluating the breeding value of plus trees, the indicators of the crown sizes of their clones are important. The results of studies of English oak (Quercus robur L.) clones crowns development from Kharkiv and Sumy regions on three clonal seed orchards (CSO) at the age of 35 and 40 years with the placement of seats $5 \times 5 \mathrm{~m}$ and $10 \times$ $5 \mathrm{~m}$ in the Kharkiv region are presented in the papaer.

When studying the development of crowns on English oak CSO for not less than 3 ramets of each clone determined the height of the tree, the diameter of the crown projection and calculated the volume of the productive part of the crown. The calculation of the optimal number of trees on the CSO, which is based on the average diameter of the projection of the crown of grafts on the $\mathrm{CSO}$, is proposed.

The low and average individual variability between the clones in height of the trees, the average - in the diameter of the crown projection, high and elevated in volume of the productive part of the crown. Clones that significantly exceed the averages for CSO at the same time in indexes of height and diameter of the crown projection (Danilovka-3 and Pechenegi-8). The most developed crowns on different CSO have clones Danilovka-3, Kochetok-36, Merchik-4, Pechenegi-8, 18, 20, 24, Sumy-27, Taranovka-18 and Sharovka-6. Correlation analysis did not reveal the relationship between the size of crowns of grafted clones and the intensity of their reproduction.

The advantages of tree height at the age of 35 were fixed at $5 \times 5 \mathrm{~m}$, while the highest indices of the crown diameters and the volume of the crown productive part were noted on the 40-year CSO with the placement of seats $10 \times 5 \mathrm{~m}$. It was revealed that before the closure of the crowns between the rows, there is a more intensive development of the crown in width, and after closure in height.

The clones' placement of on CSO $5 \times 5 \mathrm{~m}$ is undesirable, since it inhibits the crowns development in width and causes the loss of half of the productive part of the crowns. When it placing grafts of $10 \times 5 \mathrm{~m}$, forming a wide spreading crown, which contributes to more intensive reproduction.

In order to improve the lighting and nutrition conditions of the trees and the productive part of the crown preservation, it is expedient to selective cutting from 15 to 20 years with the removal of trees. The optimal number of trees should be calculated based on the average diameter of the crown projection. The long-term exploitation of English oak CSO is advisable when carrying out timely thinning and preservation of the maximum size of the productive part of the crown.

Key words: clone; height; crown projection diameter; productive part of the crown. 